\title{
Short-Term Variation of Meiobenthic Harpacticoid Copepods in a Sea Bream Mursery Pond: Effects of Environmental Changes and Predation
}

\author{
NOZOMU IWASAKI \\ Usa Marine Biological Institute, Kochi University
}

\begin{abstract}
IWASAKI, NozomU (Usa Marine Biological Institute, Kochi University). 1995. Short-Term Variation of Meiobenthic Harpacticoid Copepods in a Sea Bream Nursery Pond: Effects of Environmental Changes and Predation. Benthos Research, 48: 1 -12.

The seasonal abundance and community structure of meiobenthic harpacticoid copepods were investigated in a nursery pond containing sea bream, Pagrus major (TEMmincK \& SCHLEGEL). Twenty-three species were collected. The mean density of total harpacticoid copepods was significantly higher in 1979 (mean \pm SD: $41.87 \pm 37.77$ individuals $\left.10 \mathrm{~cm}^{-2}\right)$ than in $1980\left(18.35 \pm 12.25\right.$ individuals $\left.10 \mathrm{~cm}^{-2}\right)$. In 1979, Amonardia normani (BRADY) was most abundant from May to mid-June, and then Longipedia sp. increased and accounted for $80.1-88.5 \%$ of the total harpacticoids in August. In 1980 seven species maintained an equilibrium in terms of species composition. There were significant differences in species diversity $H^{\prime}$ and evenness $J$ ' between the two years. These differences might have been caused by two main following factors. First, the harpacticoid copepod community was not continuous due to the draining of the pond water in winter and replenishment with sea water in the spring. Second, in 1980 the density of juvenile sea bream was nearly one order of magnitude higher than in 1979, so their predation impact on meiobenthic copepods was greater in 1980 .
\end{abstract}

\section{Introduction}

The seasonal abundance of harpacticoid copepods has been studied by many field researchers. It is known that the population density gen-

Received July 16, 1994 : Accepted October 31, 1994 erally reaches its maximum during the warmer months (Hicks \& Coull, 1983). Studies of seasonal abundance over a number of years have shown that patterns of seasonal change are similar between years, though densities may vary (HARRIS, 1972; JEWETT \& FEDER, 1977; BELL, 1979; SOYER, 1980). BELL (1979) concluded that the 
patterns of seasonal abundance are influenced by environmental changes that limit immigration and reproduction. In the case of an artificial pond where the water is replenished during certain times of the year, it is predicted that the seasonal abundance and community structure will change drastically from year to year.

This paper reports the seasonal abundance and community structure of meiobenthic copepods in a nursery pond of sea bream, Pagrus major (TEMminck \& SCHLEGEL), and discusses the effects of environmental changes and predation by juvenile sea bream on meiobenthic copepods.

\section{Materials and Methods}

Study site: The study was carried out at the Momoshima Station of the Japan Sea Farming Association, located on Momo Island, Hiroshima, Japan. The station has three ponds. Sea breams have been raised from larvae to juveniles in these ponds under semi-natural conditions since 1978. The methods used at the station differ from the intensive culture methods used in tanks that are under totally artificial control. The larval-juvenile sea breams in the Momoshima ponds feed on natural plankton and small benthic animals, whose growth is enhanced by the application of manure and fertilizer to the ponds.

This study was carried out at the Number One Pond, which is the largest of the three ponds. The pond has an area of $9000 \mathrm{~m}^{2}$ and a maximum depth of $2 \mathrm{~m}$. The bottom of the pond is sandy. There is a sea water inlet on the north side (sea side) of the pond, and there are three sea water outlets on the east and south sides (Fig. 1). Sea water is drained at low tide and flows back in at high tide. There is a central longitudinal bank $(80 \mathrm{~m} \times 6 \mathrm{~m})$ to facilitate harvesting juvenile fish and to promote the circulation of sea water in the pond. The depth of the sea water over the bank is $0.5 \mathrm{~m}$. The bottom of the pond is dried for cleaning every year from winter to spring before the beginning of sea bream

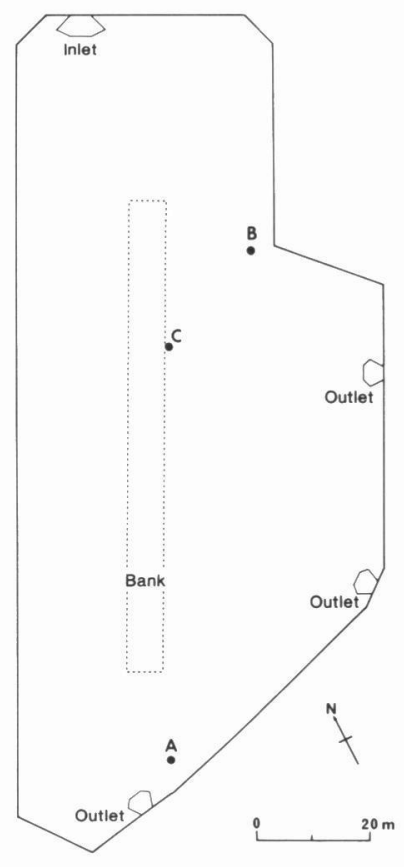

Fig. 1 Sampling stations in a sea bream nursery pond, Momo Island, Hiroshima, Japan.

culture.

On 12 April 1979, $385 \mathrm{~kg}$ of chicken manure and $80 \mathrm{~kg}$ of chemical fertilizer were added to the dry pond before filling it with sea water. $5.49 \times$ $10^{6}$ larval sea bream, ranging from 3.0 to $8.7 \mathrm{~mm}$ in total length, were released into the pond between 12 April and 31 May. 63,700 grown juvenile sea bream, ranging from 52.4 to $108.6 \mathrm{~mm}$ in total length, were harvested between 6 July and 8 September. In 1980, sea water was introduced to the pond on 1 May and $90 \mathrm{~kg}$ of chicken manure and $72 \mathrm{~kg}$ of chemical fertilizer and ammonium sulfate were added to the pond between 10 May and 22 May. $4.9375 \times 10^{7}$ larvae, ranging from 3.0 to $5.6 \mathrm{~mm}$ in total length, were released into the pond between $23 \mathrm{May}$ and 5 June. $1.3 \times 10^{5}$ juvenile sea bream of $48.8 \mathrm{~mm}$ in average total length 
were harvested between 31 July and 3 August. At the beginning of cultivation (17 April - 6 June 1979; 1 May - 8 June 1980), natural zooplankton was collected by using lights in the sea adjacent to the pond and was pumped up to the pond as food for the fish. In addition, newly hatched nauplii of brine shrimp, Artemia, and cultured rotifers, Brachionus plicatilis MüLLER, were supplied. When the sea bream grew larger than $20 \mathrm{~mm}$ in total length, minced krill and fish were fed to them.

Sampling methods and data analysis: Samplings were carried out at regular intervals during the periods of sea bream cultivation in 1979 and 1980. In 1979, samples were collected from Stns A, B and C, where depths ranged from $0.7 \mathrm{~m}$ to $1.3 \mathrm{~m}$ (Fig. 1), once a week from 16 April to 11 June and then twice a week until 30 August. In 1980 , samples were collected at Stn B at 7- to 10-day intervals between 16 May and 28 August. Sediment samples were collected down to the redox layer (depth: $6 \mathrm{~cm}$ ) by hand coring with a $4 \mathrm{~cm}$ internal diameter core tube during the day time. Triplicate samples were taken at each sampling station. Water temperature and dissolved oxygen were measured with a Horiba Ltd. Water Quality Checker, Model U-7, at the surface and on the bottom at each station. The relative density of the water was also measured at the surface with a hydrometer and converted to salinity.

Sediment samples were placed in 3-liter beakers with filtered sea water and stirred. The supernatant was then filtered through a $149 \mu \mathrm{m}$ mesh sieve. This process was repeated three times. The filtrate was immediately fixed in a $5 \%$ formalin - Rose Bengal solution, and the meiobenthic copepods were sorted and identified in the laboratory. Cephalothorax and body length of the copepods were measured with an ocular micrometer under a stereomicroscope.

Preston's formula (Preston, 1962a, 1962b) was used to examine similarities in the meiobenthic copepod community between 1979 and 1980 . The species diversity $H^{\prime}$ and evenness
$J$ ' (Shannon \& Weaver, 1949; Pielou, 1966) were calculated. One-way analysis of variance (ANOVA) was used to test for significant differences in the data between years.

\section{Results}

Hydrography: The water temperature, salinity and dissolved oxygen at $\operatorname{Stn} B$, a representative station, are shown in Fig. 2 . In 1979 the water temperature rose rapidly in mid-May, dropped at the end of June due to rain, and then rose to over $30^{\circ} \mathrm{C}$ for the remainder of the summer. In 1980 the variation in temperature was similar to that in 1979 , but the absolute temperature was higher. The salinity in 1979 was stable through the investigation period except for a sudden drop due to rain in late June and early July. In 1980 the salinity was lower and fluctuated more than in 1979. The dissolved oxygen in 1979 varied from $3.9 \mathrm{ml} \ell^{-1}$ to $8.8 \mathrm{ml} \ell^{-1}$, and it was greater in 1980 than in 1979. The higher dissolved oxygen during the initial period of investigation in both years might have been caused by phytoplankton blooms that were stimulated by the addition of fertilizer. The gradual fall in dissolved oxygen might have resulted from the decomposition of organic matter on the bottom of the pond.

Harpacticoid fauna: A total of 23 species of harpacticoid copepods was identified (Table 1 ). They were all meiobenthic copepods with the exception of Microsetella norvegica Вовск. The most abundant species were Longipedia sp. and Amonardia normani (BRADY) in 1979 and Longipedia sp. and Schizopera sp. in 1980. Twenty species were collected in 1979 , and 18 in $1980 ; 15$ species were common to both years. Since the expected number of species in common, calculated using PRESTON's formula, is 15.0, the harpacticoid fauna during those two years was very similar.

Seasonal variation and community structure: The mean densities of total harpacticoid copepods at three stations in 1979 and one 


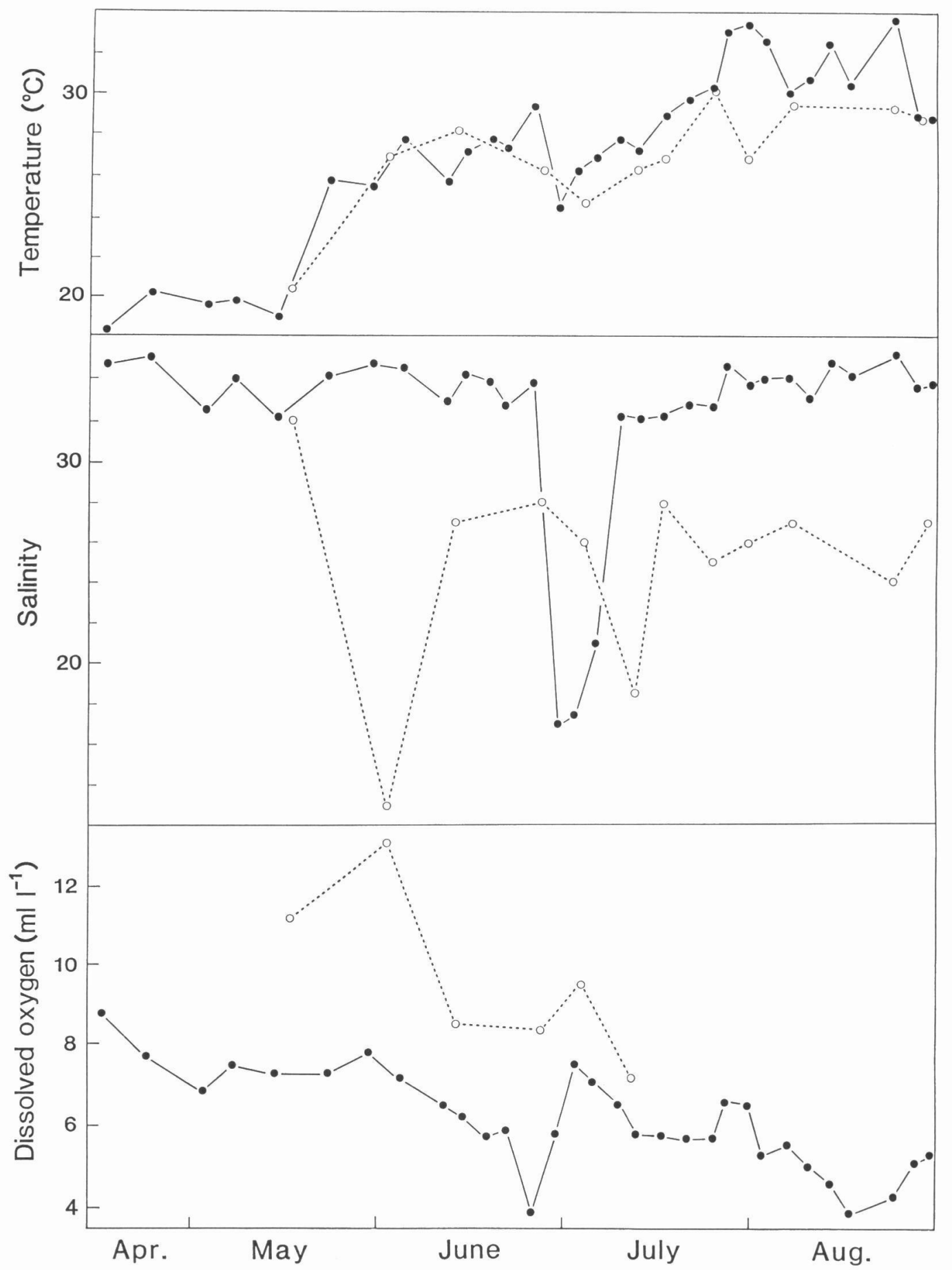

Fig. 2 Seasonal variation in water temperature, salinity and dissolved oxygen at Stn. B for 1979 (closed circles) and 1980 (open circles). 
Table 1 Species list and mean density (individuals $10 \mathrm{~cm}^{-2}$ ) of harpacticoid copepods from the sea bream nursery pond in 1979 and 1980 . 'The values are the average of three stations. "*Total copepods include unidentified species.

\begin{tabular}{|c|c|c|c|c|}
\hline & \multicolumn{2}{|c|}{1979} & \multicolumn{2}{|c|}{1980} \\
\hline & Mean ${ }^{*}$ & $\mathrm{SD}$ & Mean & SD \\
\hline Longipedia sp. & 28.53 & 32.99 & 3.82 & 4.59 \\
\hline Halectinosoma sp. & 0.003 & 0.03 & 0.13 & 0.21 \\
\hline Microsetella norvegica & 0.11 & 0.25 & 0.02 & 0.08 \\
\hline Tachidius sp. & & & 0.11 & 0.24 \\
\hline Harpacticus sp. & 0.05 & 0.23 & 0.04 & 0.10 \\
\hline Tisbe sp. & 0.38 & 2.97 & 0.40 & 1.14 \\
\hline Dactylopodia sp. & 1.87 & 3.38 & 0.95 & 1.70 \\
\hline Eudactylopus sp. & 0.01 & 0.06 & & \\
\hline Parastenhelia sp. A & 0.09 & 0.21 & 0.44 & 0.56 \\
\hline Parastenhelia sp. B & & & 1.17 & 1.38 \\
\hline Amphiascus sp. A & 0.87 & 1.02 & 1.53 & 1.55 \\
\hline Amphiascus sp. B & 0.58 & 0.91 & 0.24 & 0.69 \\
\hline Amphiascus sp. C & 0.25 & 0.79 & 0.13 & 0.31 \\
\hline Mesamphiascus sp. & 0.70 & 1.40 & 2.52 & 1.65 \\
\hline Amonardia normani & 6.57 & 11.19 & 1.13 & 1.45 \\
\hline Robertgurneya sp. & & & 0.27 & 0.55 \\
\hline Schizopera sp. & 0.25 & 0.63 & 3.45 & 3.15 \\
\hline Ameira parvula & 1.27 & 4.03 & 1.15 & 1.39 \\
\hline Nitocra sp. & 0.04 & 0.14 & & \\
\hline Onychocamptus sp. & 0.04 & 0.11 & & \\
\hline Laophontidae sp. A & 0.16 & 0.45 & & \\
\hline Laophontidae sp. B & 0.06 & 0.20 & 0.02 & 0.08 \\
\hline Laophontidae sp. C & 0.04 & 0.15 & & \\
\hline Total copepods ${ }^{*}$ & 41.87 & 37.77 & 18.35 & 12.25 \\
\hline
\end{tabular}

station in 1980 are presented in Fig. 3 . In 1979 the density of total copepods began to increase in the middle of May and reached maximum levels in July. The three stations followed the same gross pattern of density variation except for late July and late August. At Stn B the density in 1980 was lower and less variable than in 1979; the mean density was higher in 1979 than in 1980, and there was a significant difference between years (one-way ANOVA, $p<0.05$, Table 1).

The seasonal variations of the four most abundant harpacticoid copepod species at Stn B in 1979 and 1980 are shown in Fig. 4 . Longipedia sp. and Dactylopodia sp. were most abundant in mid-summer in both years. Anormani and Ameira parvula ClaUs were most numerous in early summer.

The size-frequency distributions of the two 


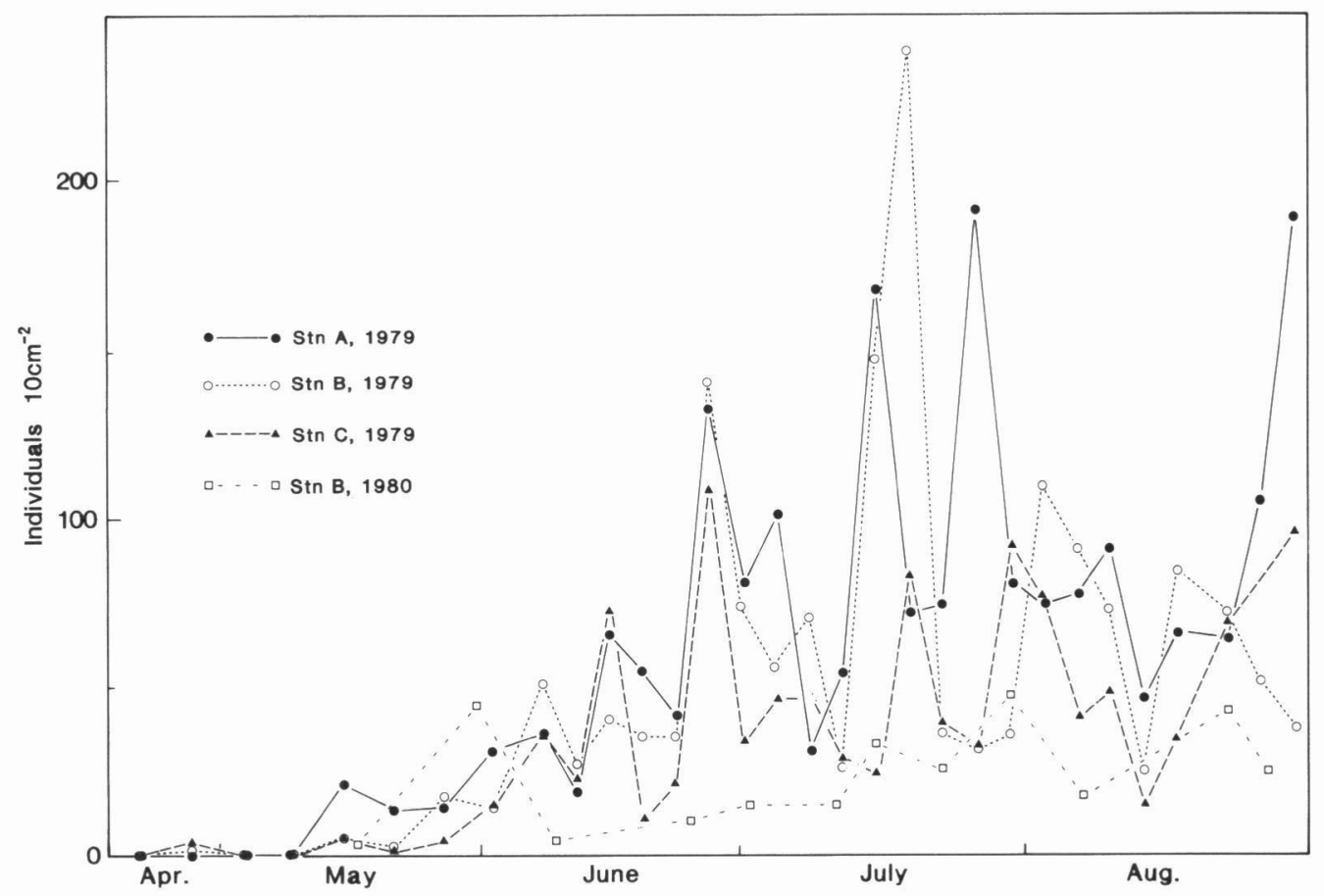

Fig. 3 Seasonal variation in the mean density of harpactıcold copepods (individuals $10 \mathrm{~cm}^{-2}$ ) in a sea bream nursery pond.

most abundant species, Anormani and Longipedia sp., were examined (Fig. 5 ). The smaller size classes of Anormani were absent during the period from 20 July to late August 1979. In 1980 , only the middle size classes were present except for early in June, and in lower numbers than in 1979. These results indicate that Anormani did not breed successfully in the pond from late July to August 1979, or during the entire study period in 1980. Furthermore, in 1980 part of the population of Longipedia sp. did not breed successfully; the frequency distribution of size classes was discontinuous in late June, between the middle of July and early August, and in late August, and the large size classes were absent after July.

The species composition was basically identical at the three stations in 1979 except for the brief appearance of Tisbe sp. in early June at
Stn B (Fig. 6). Anormani was the most abundant species during the early period of investigation at all three stations. Afterwards, Longipedia sp. increased in number and comprised $80.1-88.5 \%$ of the total copepods taken in August. Ameira parvula and Dactylopodia sp. occurred from June through August. From these facts, it seems that there was only one harpacticoid community in the pond that year. The seasonal pattern of species composition at Stn B in 1980 differed from that in 1979. In 1980 seven species maintained an equilibrium in terms of species composition: no single species dominated, but Longipedia sp. accounted for an average of $42.0 \%$ in the August samples.

The value of $H^{\prime}$ was significantly lower in 1979 (average $1.30 \pm 0.64$ ) than in 1980 (average $2.71 \pm 0.38$; one-way ANOVA, $p<0.01$ ). The value of $J$ ' was also significantly less in 1979 
Short-term variation of harpacticoids

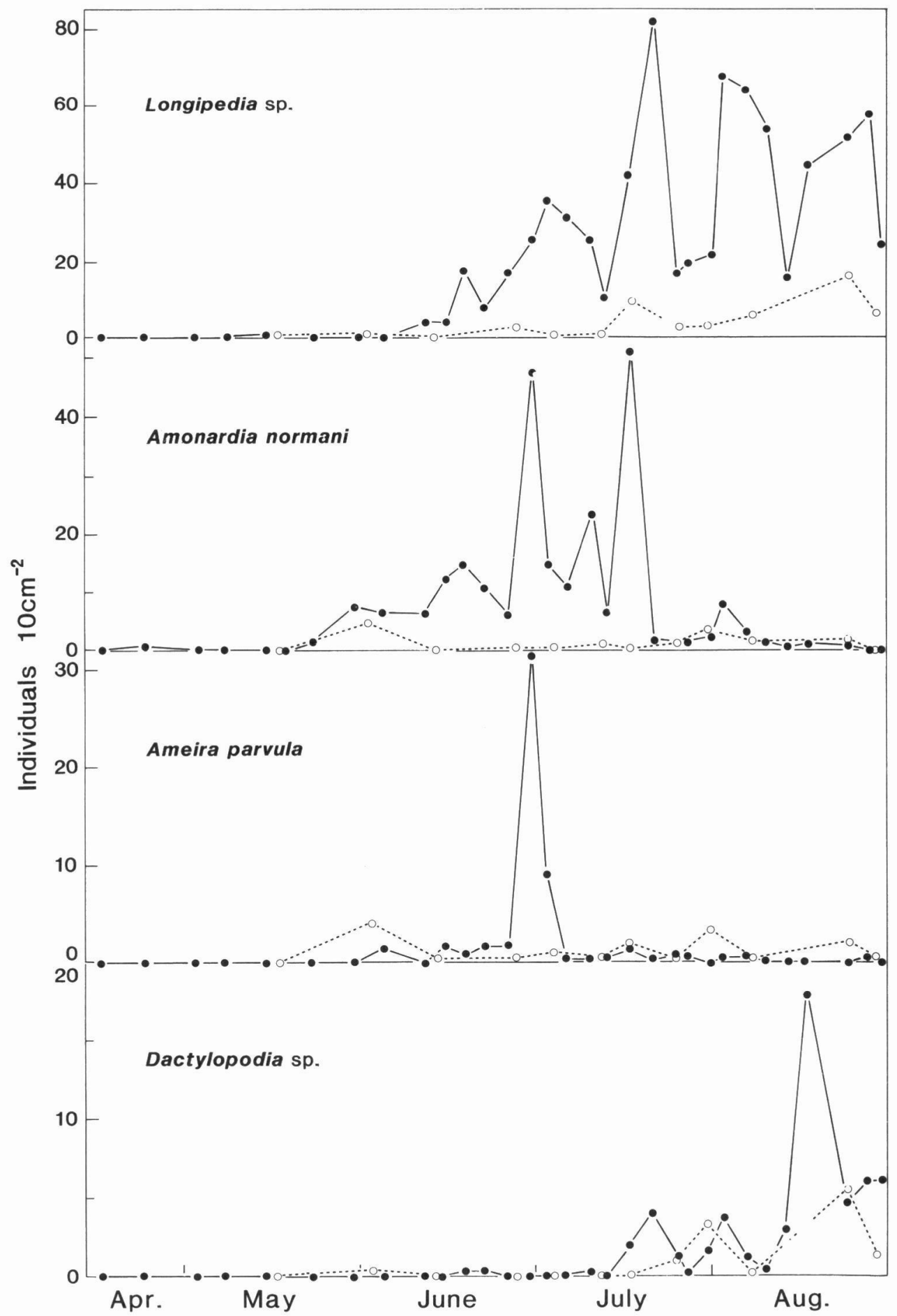

Fig. 4 Seasonal variation in the mean density of the four most abundant harpacticoid copepods at Stn B for 1979 (closed circles) and 1980 (open circles). 


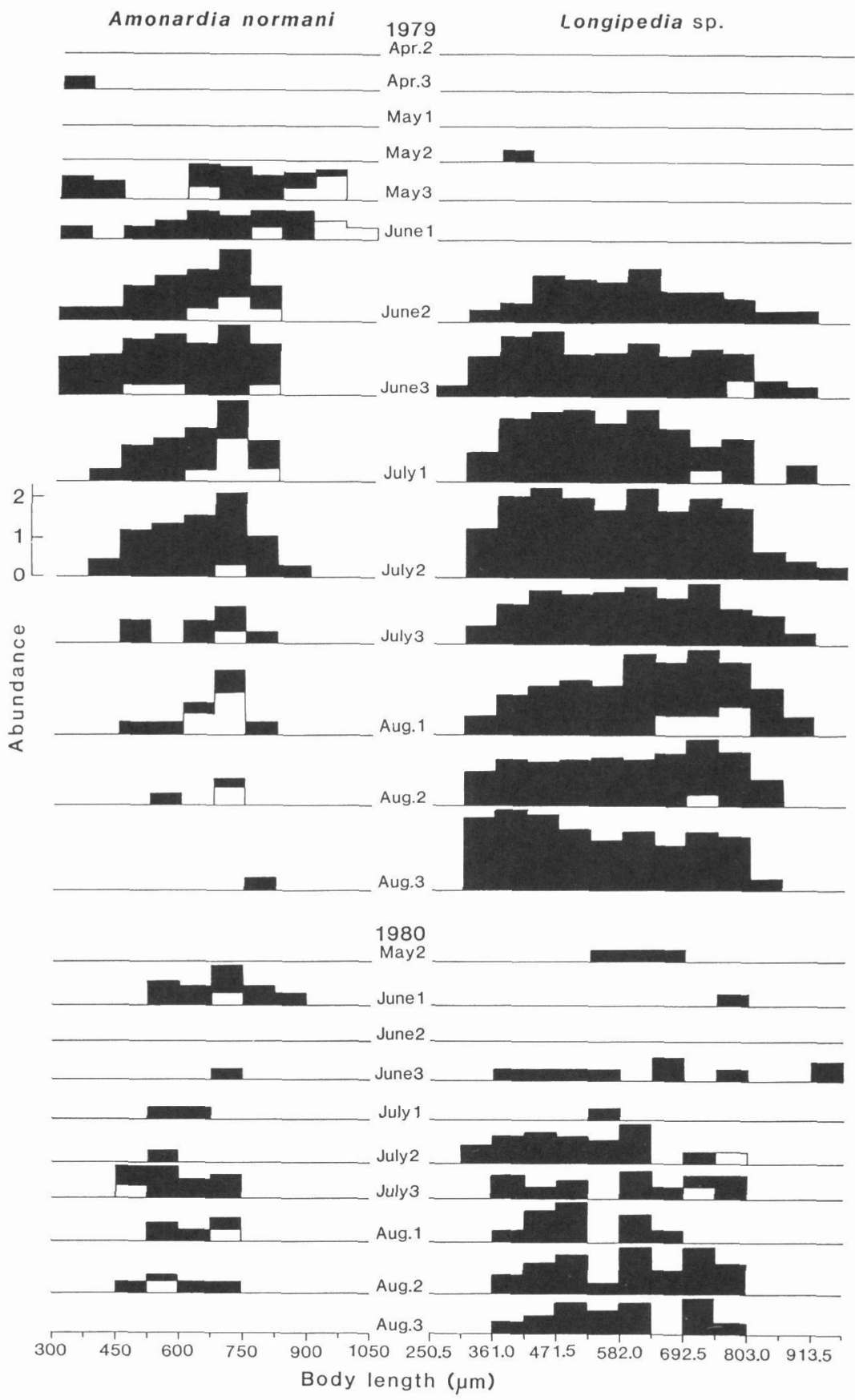

Fig. 5 Size-frequency distributions of female and unsexed copepodites of Amonardia normani (left) and Longipedia sp. (right) at Stn B. Abundance is expressed by $\log _{10}(1+$ Number). White areas represent ovigerous females. Abbreviations: $1=$ first ten days of a month; $2=$ second ten days of a month; $3=$ last ten days of a month. Apr.2, for example, means the second ten days of April. 


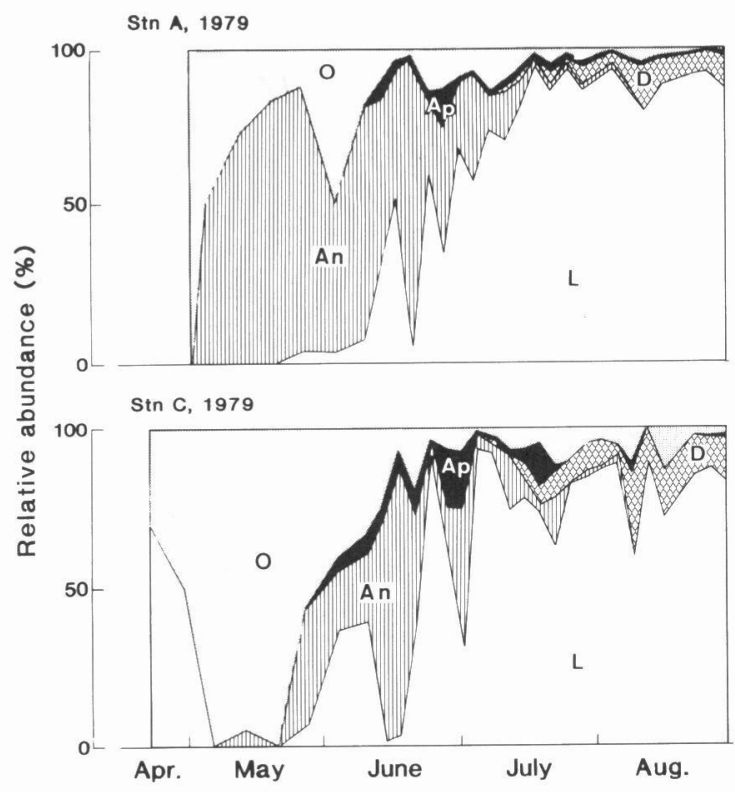

Stn B, 1979

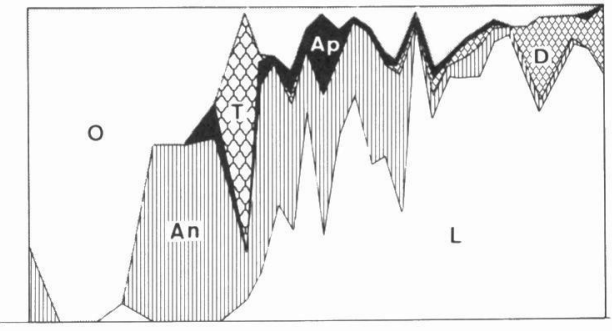

$\operatorname{Sin} B, 1980$

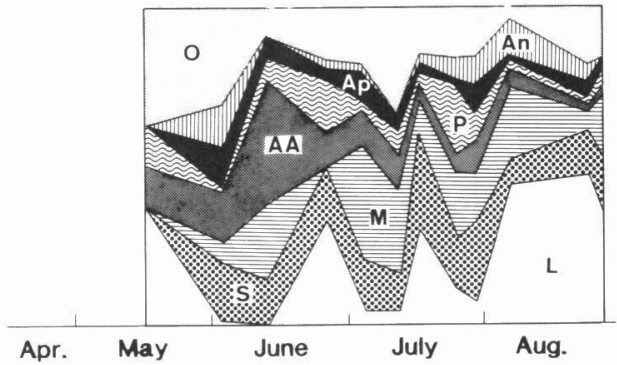

Fig. 6 Seasonal variation in major taxa of harpacticoid copepods. Abbreviations: AA= Amphiascus sp. A ; $\mathrm{An}=$ Amonardia normani ; $\mathrm{Ap}=$ Ameira parvula $; \mathrm{D}=$ Dactylopodia sp.; $\mathrm{L}=$ Longipedia sp.; $\mathrm{M}=$ Mesamphiascus sp.; $\mathrm{O}=$ Others; $\mathrm{P}=$ Parastenhelia sp. B; $\mathrm{S}=$ Schizopera sp.; $\mathrm{T}=$ Tisbe sp.

(average $0.49 \pm 0.24$ ) than in 1980 (average $0.84 \pm$ 0.07 ; one-way ANOVA, $p<0.01$ ).

\section{Discussion}

The seasonal changes of the mean density of total copepods in 1979 and 1980 were apparently influenced by temperature and dissolved oxygen. The increase of the mean density from May coincided with an increase in temperature. The four most abundant species also reached their maximum abundances during the high temperature season, in the same manner as seen in previous studies (Hicks \& Coulll, 1983). The decreases of the mean density in late June and mid-August 1979 and in mid-June 1980 coincided with decreases in dissolved oxygen in the pond environment. Furthermore, it seems that the decrease of the mean density on 3 August 1980 was due to a disturbance of the pond bottom caused by fish harvesting activity. The lack of correlation between the variations in mean density among the three stations in July and August 1979 is also thought to be due to bottom disturbance caused by fish harvesting activity.

The findings described above show that the harpacticoid copepod fauna in 1979 and 1980 was very similar in terms of species present, but that the community structure represented by $H^{\prime}$ and $J$ ' during the two years was very different. This is in contrast to FLEEGER'S (1980) results, which did not show a large difference in mean values over a four-year period at an estuary along the South Carolina coast. In the present study, the pond that was investigated was dried and tilled before starting sea bream culture every year. As 
a result, the harpacticoid community was not continuous. Harpacticoid copepods colonize the pond and then the resulting harpacticoid community is destroyed every year. In addition, factors that affect the formation of harpacticoid copepod communities, such as food resources, structural heterogeneity, disturbance by macrofauna, predation by macrofauna and larval-juvenile fishes, and competition (BELL, 1979, 1980; Hicks \& Coull, 1983) change yearly. A new harpacticoid community, therefore, appears every year under the influence of these factors.

Although Anormani is well-adapted to stressed, semi-enclosed lagoons, owing to its short generation time and high reproductive potential (CASTLE, 1979), it did not maintain its population in this study. The dominant species changed from $A$. normani to Longipedia sp. in the summer of 1979 . This is probably either because an environment suitable for Longipedia sp. was formed in the summer or because Longipedia sp. won the species competition. It is known that two species of Longipedia are capable of fertilizing multiple batches of eggs in a single initial mating (HICKs \& Coull, 1983; ONBE \& Кiмото, 1985). OnBE \& КiмоTo (1985) concluded this reproductive strategy would be very advantageous in an ever-changing coastal environment.

It is well known that harpacticoid copepods are an important food source for larval-juvenile fish (Bodiou \& Villiers, 1979; Gordon \& Duncun, 1979; Grossman et al., 1980; Tito de Morais \& Bodiou, 1984; HICKs, 1985; WeBB, 1991a). It is also known that the density of harpacticoid copepods is lowered drastically by juvenile fish predation (SiBERT, 1979) and that the total number of meiobenthic copepods is significantly reduced by spot, Leiostomus xanthurus LACÉPÉDE (SERvice et al., 1992). WeBB (1991a, 1991b) reported that the impact of predation by juvenile Pacific salmon, Oncorhynchus spp., on the harpacticoid copepod population was minimal. The juvenile sea bream (5-15mm in total length) in this study fed on harpacticoid copepods for a period of about two months from the end of May to the beginning of July 1979, according to OHNO (1992). He reported that the main food for sea bream over $15 \mathrm{~mm}$ in total length was amphipods, and not harpacticoid copepods. The variation in the mean density of copepods increased steadily during this period, with the exception of insignificant temporary decreases. The effect of predation by sea bream on meiobenthic copepods, therefore, does not greatly inhibit the reproduction of copepods. In 1980, the number of sea bream which were put in the pond was increased by about ten times over that of 1979 . In this case, the main food for the juvenile sea bream, even those over $15 \mathrm{~mm}$ in total length, was harpacticoid copepods, since amphipods were absent (OHNO, 1992). For this reason, it is assumed that the effect of predation was higher in 1980 than in 1979. The low density of total copepods and lack of large size classes and some middle size classes of Longipedia sp. and $A$. normani might have been due to predation by sea bream. Although there is a division of opinion concerning the impact of predation by juvenile Pacific salmon on harpacticoid copepods (WEBB, 1991a, 1991b), the results of this study show that the impact of fish predation may depend on the presence or absence of alternative prey such as amphipods.

\section{Acknowledgments}

I am grateful to Shogoro KaSAhara, Professor Emeritus of Hiroshima University, and Shin-ichi UyE of the Faculty of Applied Biological Science, Hiroshima University, for their attention and guidance of this subject. I would like to thank Jean-Yves Bodiou of the Laboratoire Arago for reading the manuscript and for useful comments and criticisms. I also acknowledge the staff of the Momoshima Station, Japan Sea Farming Association, for their kind assistance. 


\section{References}

BELL, S.S., 1979. Short- and long-term variation in a high salt marsh meiofauna community. Est. Cstl. Mar. Biol. Ecol., 9: 331- 350.

BELL, S.S., 1980. Meiofauna-macrofauna interactions in a high salt marsh habitat. Ecol. Monogr., 50: 487-505.

Bodiou, J.-Y. and L. Viluiers, 1979. La prédation de la meiofauna par les formes juvéniles de Deltentosteus quadrimaculatus (Teleostei, Gobiidae). Vie Milieu, Sér. AB, 28-29: 143156.

CASTEL, J., 1979. Adaptation and reproductive cycle of the harpacticoid copepod Amonardia normani (BRADY, 1872) in semienclosed lagoons of Arcachon Bay, France. In, Cyclic phenomena in marine plants and animals, ed. by E. NAYLOR and R.G. Hartnol, Pergamon Press, Oxford, pp. 131138.

FLEEGER, J.W., 1980. Community structure of an estuarine meiobenthic copepod assemblage. Est. Coast. Mar. Sci., 10: 107-118.

GoRdon, J.D.M. and J.A.R. DunCAN, 1979. Some notes on the biology of the snake blenny, Lumpenus lampretaeformis on the west coast of Scotland. J. Mar. Biol. Ass. U. K., 59: 413- 419 .

Grossman, G.D., R. Coffin, and P. Moyle, 1980. Feeding ecology of the bay goby (Pisces: Gobiidae). Effects of behavioral, ontogenetic, and temporal variation on diet. J. Exp. Mar. Biol. Ecol., 44: 47-59.

HARRIS, R.P., 1972. Seasonal changes in population density and vertical distribution of harpacticoid copepods on an intertidal sand beach. J. Mar. Biol. Ass. U. K., 52: 493-505.

Hicks, G.R.F., 1985. Biomass and production estimates for an estuarine meiobenthic copepod, with an instantaneous assessment of exploitation by flatfish predators. N. Z. J. Ecol., 8: 125-127.

Hicks, G.R.F. and B.C. Coull, 1983. The ecology of marine meiobenthic harpacticoid copepods. Oceanogr. Mar. Biol. Ann. Rev., 21: 67-175.

JewetT, S.C. and H.M. Feder, 1977. Biology of the harpacticoid copepod, Harpacticus uniremis KroYer on Dayville Flats, Port Valdez, Alaska. Ophelia, 16: 111-129.

ОнNо, А., 1992. Fundamental study on the extensive seed production of the red seabream, Pagrus major. Tokubetsu Kenkyu Hohkoku, Japan Sea Farming Association, 2: 1-110 (in Japanese, with English abstract).

OnBE, T. and Y. KiмOTo, 1985. Growth and reproduction of Longipedia sp. (Copepoda: Harpacticoida) in laboratory cultures. Spec. Publ. Mukaishima Mar. Biol. St. 1985, pp. 205-212.

PIELOU, E.C., 1966. The measurement of diversity in different types of biological collection. $J$. Theoret. Biol., 13: 131-144.

Preston, F.W., 1962a. The canonical distribution of commonness and rarity: Part I. Ecology, 43: 185-215.

Preston, F.W., 1962b. The canonical distribution of commonness and rarity: Part II. Ecology, 43: 410-432.

Service, S.K., R.J. Feller, B.C. Coull and R. Woods, 1992. Predation effect of three fish species and a shrimp on macrobenthos and meiobenthos in microcosms. Est. Coast. Shelf Sci., 34: 277-293.

Shannon, C.E. and W. Weaver, 1949. The mathematical theory of communication. University of Illinois Press, Urbana, $125 \mathrm{pp}$.

SibERT, J.R., 1979. Detritus and juvenile salmon production in the Nanaimo Estuary: II. Meiofauna available as food to juvenile chum salmon (Oncorhynchus keta). J. Fish. Res. Bd Can., 36: 497-503.

SOYER, J., 1980. Cycle biologique d'un copépode harpacticoide des vases terrigènes côtières de Banyuls-sur-Mer: Cletodes pusillus (SARS). Vie Milieu, 30: 35-44.

Tito DE Morais, L. and J.Y. Bodiou, 1984. Predation on meiofauna by juvenile fish in a 
Western Mediterranean flatfish nursery ground. Mar. Biol., 82: 209-215.

WEBB, D.G., 1991a. Effect of predation by juvenile Pacific salmon on marine harpacticoid copepods. I. Comparisons of patterns of copepod mortality with patterns of salmon consumption. Mar. Ecol. Prog. Ser., 72: 2536.

WeBB, D.G., 1991b. Effect of predation by juvenile Pacific salmon on marine harpacticoid copepods. II. Predator density manipulation experiments. Mar. Ecol. Prog. Ser., 72: 37-47.

\section{和文要旨}

岩崎 望 マダイ種苗生産池における底棲性かいあ し類ハルパクチクス類の変動.

日本栽培漁業協会百島実験地（広島県）のマダイ種 苗生産池で, ハルパクチクス類群集の変動に関する研 究を行った。調查は, 1979年 $4 \sim 8$ 月, 1980年 $5 \sim 8$ 月のマダイ種苗生産期に行った. 両年のハルパクチク ス類群集を比較すると, 平均出現個体数は1979年

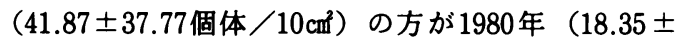
12.25 個体 $\left./ 10 \mathrm{~cm}^{2}\right)$ よりも多かったが, 種多様度 $\left(H^{\prime}\right)$, 均衡性指数 $\left(J^{\prime}\right)$ は, 1979 年 $\left(H^{\prime}=1.30 \pm 0.64, J^{\prime}=\right.$
$0.49 \pm 0.24 ）$ の方が 1980 年 $\left(H^{\prime}=2.71 \pm 0.38, J^{\prime}=\right.$

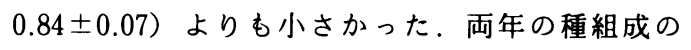
変化を比較すると，1979年は 5 月から 6 月中旬まで Amonardia normani (BRADY) が多く, その後 Longipedia sp. が増加した. 8 月には, Longipedia sp. は全個体数の $80.1 〜 88.5 \%$ を占めた. 一方, 1980 年は優占種はなく, 調查期間を通じて 7 種が均衡して いた. また, 両年の A. normani と Longipedia sp. の体長頻度分布の変化を比較すると, 1980年は両種と あ小さなサイズと大きなサイズの個体は出現しなかっ た.これら両年の差異は,次の理由によると考えられ る. 池の海水は種苗生産が終わると排出され, 池は干 出される.そして, 種苗生産開始前に地先海水が池に 導入される. ハルパクチクス類群集は, 池の干出によっ て破壊され, 海水の導入に伴い新たな群集が形成され る.このため, 年により群集構造は異なることになる. また, マダイ種苗の収容数は, 生産開始時で1980年 （4937.5万匹）は1979年（549万匹）に比べて約10倍多 かった。 マダイ収容数の増加がハルパクチクス類への 補食圧の增加を招き，ハルパクチクス類の減少と体長 頻度分布の变化をもたらしたと考えられる.

\section{Nozomu IW ASAKI}

Usa Marine Biological Institute, Kochi University, 194, Inoshiri, Usa-cho, Tosa City, Kochi 781-11, Japan 